\title{
Analysis Of Travel Business Competitive Strategy (Case Study In PT. Jasa Tour And Travel Medan)
}

\author{
Sonia Benedicta Simanjuntak
}

Department of Business Administration Science, University Of North Sumatra, Indonesia.

$\begin{array}{r}\hline \hline \text { A R T I C L E I N F O } \\ \hline \text { Article history: } \\ \text { Received Nov 01, } 2021 \\ \text { Revised Des 03, } 2021 \\ \text { Accepted Jan 30, } 2022 \\ \hline\end{array}$

Keywords:

Competitive Strategy SWOT Analysis

\begin{abstract}
Business competition is a common thing in the corporate world. As time goes by, business competition faced by the company is also getting tougher. This requires the company to be more careful in formulating a strategy to win the competition. Seeing the fierce increasing competition, the authors observed that PT. JAS Tour and Travel needs to establish the exact formulation of competitive strategy to find the factors of internal and external key that can affect the level of success of the strategy. Strength of business travel agencies will be capital in competitive advantage of opportunities that exist.This study aims to determine competitive strategy what is the most appropriate for use by PT. JAS Tour And Travel in order to maintain the existence amid increasing fierce competition. The strategy formulated by analyzing the internal and external forces, and the opportunities and threats of the company. The method used is a qualitative descriptive study to identify the strengths, weaknesses, opportunities and threats. Analysis of the data used is the data collection phase, the stage of data analysis and decisionmaking stage.Based on research conducted by SWOT analysis as a media strategy formulation, PT. JAS Tour And Travel supports aggressive strategy. The input stage includes EFE matrix with a total value of 2.85 and IFE matrix with a total value of 2.90 . While the results of the matrix $\mathrm{CP}$ is known that the indicators of competition are: PT. JAS Tour And Travel 3.85, Senandika Tour And Travel amounted to 3.60, and Manalu Jaya Travel at 3.65. SWOT matrix matching phase and the matrix IE. SWOT analysis showed that PT. JAS Tour And Travel is in quadrant I, which states that PT. JAS Tour And Travel supports aggressive strategy. From the matrix IE, known that. JAS Tour And Travel is in quadrant $V$ which is a strategy to preserve and defend. Therefore, PT. JAS Tour And Travel can consider two alternative strategies, namely market penetration and product development. Phase decision to use a QSPM matrix and obtained a total value of the highest appeal and the right to apply the company is a market penetration strategy with a value of 6.00 . The proposed strategy can be applied to improve the quality of services and conduct market development.
\end{abstract}

This is an open access article under the CC BY-NC license.

\section{Corresponding Author:}

Sonia Benedicta Simanjuntak,

Department of Business Administration Science,

University Of North Sumatra, Indonesia,

Jl. Dr. Mansur No. 9 Padang Bulan, Kec. Medan Baru, Kota Medan 20222.

Email: soniasimanjuntak@gmail.com 


\section{INTRODUCTION}

Strategy is the main thing that needs to be designed in such a way in the face of competition. Competition is a situation when organizations fight or compete to achieve desired results or goals such as consumers, market share, survey ratings, or required resources (Mudrajad, 2005: 86). To win the competition requires the right competitive strategy and new innovations that can make a business able to survive in a competitive environment. Strategy emphasizes how a business acts in the face of business competition, with efforts to increase customer satisfaction through improving the attitude of business operations in order to achieve the expected performance in the objectives of a business.

Competition is very important to the success or failure of a business. Competition determines the activities that are necessary for each business/business to excel, such as innovation, a cohesive culture, or good implementation. Competitive strategy aims to build a profitable and strong position against the forces that determine competition in business, including in the service business.

According to Philip Kotler, service is any activity or benefit offered by one party to another, which is essentially intangible and does not result in any ownership. Services do not result in any ownership like products, because services are invisible in nature, but in the form of providing assistance in satisfying customer needs and or desires with or without certain rewards in return. There are six service characteristics that need to be considered by service providers, namely intangibility (not visible), Perishability (cannot be stored), Heteroginity (varies), inseparability (cannot be separated between production and consumption), people based (very dependent on employee performance) and contact customer (direct contact with consumers).

In addition, service providers can choose alternative service product strategies, namely: market penetration, market development, service product development and verification. Which strategy to choose depends on the situation of each company. For service providers who want to diversify, they must utilize technology and innovate, so that they can produce service products that are able to provide solutions for customers. The success of service providers in providing services is highly dependent on the role of several parties such as employees, consumers and intermediaries. For this reason, companies must be able to build good relationships based on the principle of a win-win situation to encourage and optimize their performance. Fostering good relations with employees can be done by increasing compensation, reducing conflict and motivation.

PT. JAS Tour and Travel is one of the travel agency services whose head office is currently located on Jl. Jamin Ginting No.690, Medan. PT. JAS Tour and Travel provides domestic, international, and ship ticketing services. In creating a competitive advantage, it is important for PT Jas Tour and Travel to know the conditions of the internal environment, namely its strengths and weaknesses and its external environment, namely the opportunities and threats it has.

The services offered by PT JAS Tour and Travel are numerous so that consumers can choose which services to use according to their needs. Although the services offered are quite diverse, it does not rule out the possibility of external threats such as increasing competitors. Competition in the world of travel agent business at this time seems to have increased significantly.

Strategic management can be defined as the art of knowledge to formulate, implement and evaluate functional decisions that enable an organization to achieve its objectives. (David, 2002:5). Companies that are unable to compete to maintain their performance will gradually be evicted from their industrial environment and will experience bankruptcy. The importance of high competitiveness is a benchmark for a business in maintaining its business continuity. Seeing the increasingly fierce competition, then PT. JAS Tour and Travel needs to determine the formulation of the right competitive strategy by finding key internal and external factors that can affect the level of strategy success. The strength of the travel agent service business will be the capital in competing to take advantage of existing opportunities.

\section{RESEARCH METHOD}


The method used in this study is a qualitative research method. Qualitative research is a research aimed at describing and analyzing phenomena, events, social activities, attitudes, beliefs, perceptions, thoughts of people individually and in groups. The data were collected with careful observation, including descriptions in a detailed context accompanied by notes from in-depth interviews, as well as the results of analysis of documents and notes (Nana Syaodih, 2012:60). In qualitative research does not use a population, because qualitative research departs from certain cases that exist in certain social situations and the results of the study will not be applied to the population. but transferred to another place in a social situation that has similarities with the social situation in the case studied. The sample in qualitative research is not called respondents, but as resource persons, or participants, informants, friends or teachers in research (Sugiyono, 2008:298).

Research that takes place at this time is called descriptive research, while research that is carried out over a long period of time is called longitudinal research. In qualitative research does not use a population, because qualitative research departs from certain cases that exist in certain social situations

\section{RESULTS AND DISCUSSIONS}

\subsection{Data analysis}

Based on interviews conducted by the author, it can be identified internal factors (strengths and weaknesses) and external factors (opportunities and threats) owned by PT. JAS Tour And Travel. The identification results will be analyzed in 3 stages, namely the input stage, the matching stage and the decision stage. Based on the results of this analysis, it will be known what competitive strategy is appropriate and can be applied by PT. JAS Tour And Travel.

\subsection{WO (Weakness-Opportunity) Strategy}

Opportunities owned by PT. JAS Tour And Travel can reduce existing weaknesses in the following ways:

\section{a. Strategy for monitoring and controlling employees}

PT. JAS Tour And Travel needs to implement a strategy of monitoring and controlling employees to improve employee performance and service quality. Thus the opportunity to get new consumers who have potential as loyal customers can be achieved.

\section{b. Business location redesign strategy}

To overcome the weakness that lies in the uncomfortable working atmosphere, PT. JAS Tour And Travel can carry out a business location redesign strategy, namely the travel office located on Jl. Jamin Ginting No. 690. With the realization of a calmer and more comfortable working atmosphere, the opportunity to get new customers who have potential as loyal customers can be achieved.

\section{c. Business location security strategy}

The location of the business office of PT. JAS Tour And Travel, which is located on the side of a major road and is crowded with residents, is indeed very prone to disturbances and security problems. For this reason, it is necessary to implement a security strategy for business locations, by routinely renewing business licenses, especially nuisance permits. Disturbance Permit $(\mathrm{HO})$ is a business activity permit to an individual/entity in a certain location that has the potential to cause harm and disturbance, peace and public order, excluding activities/business places whose location has been designated by the Central or Regional Government.

\subsection{ST Strategy (Strength-Threat)}

Based on the strength of PT. JAS Tour And Travel can then avoid the existing threats with the following strategies:

\section{a. Business program development strategy}


PT. JAS Tour And Travel should be able to take advantage of the quality of service and increase promotional activities so that even though the operational costs required are high, the development of business programs can still be carried out.

\section{b. Strategy to improve the quality of services and services}

The emergence of various online ticket sales applications and many similar businesses are a threat to PT. JAS Tour And Travel. For this reason, it is necessary to improve the quality of services and services so that customers do not switch to other travel options.

\subsection{WT (Weakness-Threat) Strategy}

To reduce existing weaknesses and avoid threats, PT. JAS Tour And Travel should implement the following strategies:

\section{a. Business program development strategy}

Business development is very important for every company. For that PT. JAS Tour And Travel needs to set aside operational costs little by little from total revenue to support the development of a variety of business programs.

\section{b. Promotion Strategy}

The number of competitors that emerged from similar travel businesses and online travel applications required PT. JAS Tour And Travel to be more active in improving weaknesses and improving promotions and service quality.

\subsection{IE Matrix}

The IE (Internal-External) Matrix consists of two dimensions, namely the total score of the IFE Matrix on the $X$ axis and the total score of the EFE Matrix on the $Y$ axis. Based on the score owned by PT. JAS Tour And Travel on the IFE Matrix of 2.90 indicates that PT. JAS Tour And Travel is in the average internal position (2.0 - 2.99).

This means PT. JAS Tour And Travel has a position of strength that can reduce its weaknesses. Meanwhile, based on the score owned by PT. JAS Tour And Travel on the EFE Matrix of 2.85 indicates that the external position is an average $(2.0-2.99)$. This means PT. JAS Tour And Travel has opportunities that can be achieved by utilizing the strengths they have, and these opportunities are trying to be utilized as much as possible.

PT. JAS Tour And Travel is located in cell V using Hold and Maintain strategies. So there are 2 alternative strategies that can be used by PT. JAS Tour And Travel Market Penetration Strategy and Product Development. According to Fred R. David (2012:252) Market penetration is a strategy that seeks to increase market share for existing products or services in the current market through greater marketing efforts. Market penetration includes increasing the number of salespeople, increasing spending on advertising, offering extensive sales promotion products, or multiplying marketing efforts. Product development is a strategy that seeks to increase sales by improving or modifying existing products or services. Product development usually requires large expenditures for research and development.

\subsection{Decision Stage}

QSPM (Quantitative Strategic Planning Matrix) is a tool recommended for strategists to evaluate alternative strategy options objectively, based on previously identified internal-external key success factors. The strategies that will be evaluated in this matrix are market penetration strategies and product development strategies. The following is the strategic decision stage of PT. JAS Tour And Travel using the QSP Matrix:

Table 1. QSP Matrix PT JAS Tour And Travel

\begin{tabular}{lccccc}
\hline \multirow{2}{*}{ Key success factors } & \multirow{4}{c}{ Alternative Strategy } \\
& Weight & Market penetration & Product Development \\
Strength & & US & BAG & US & BAG \\
\hline
\end{tabular}




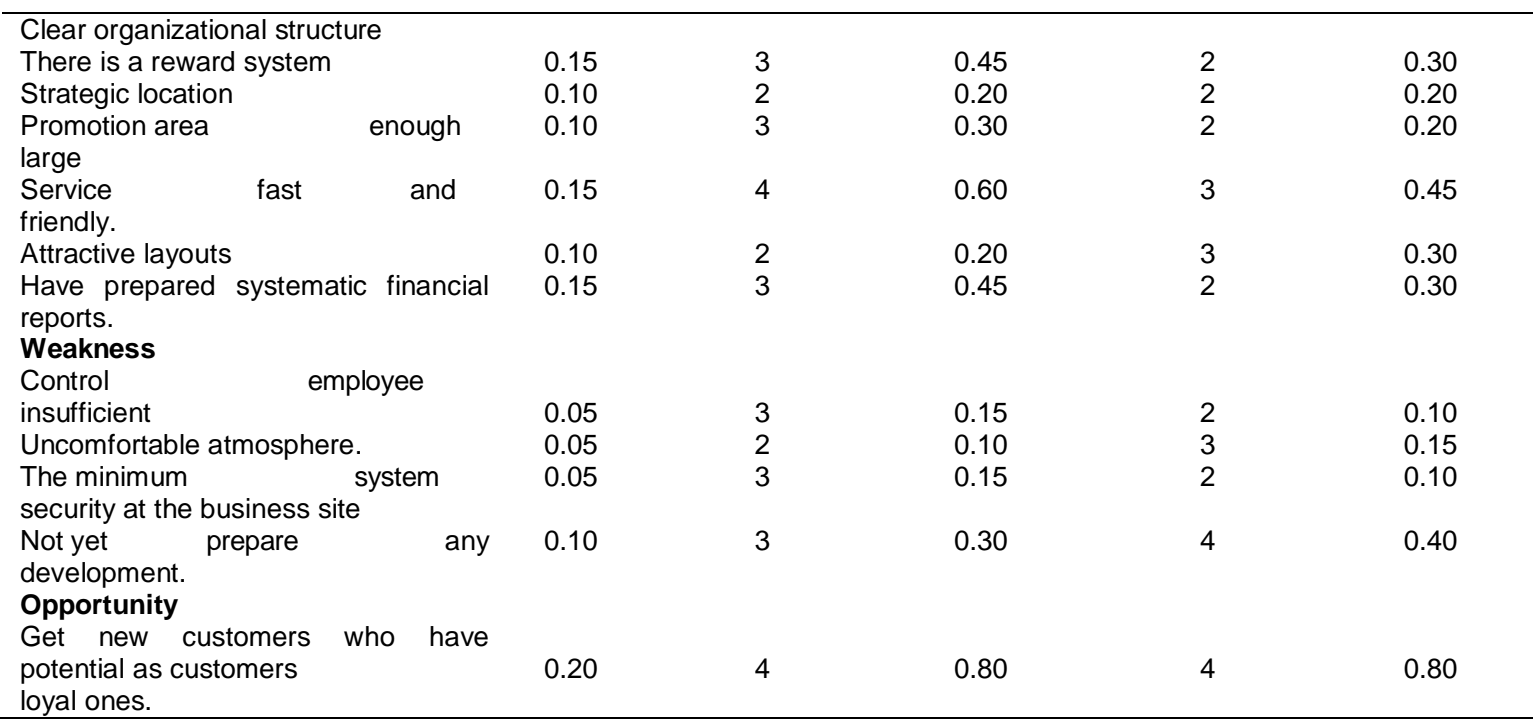

Based on the results of the QSP Matrix above, the appropriate competitive strategy that can be applied by PT. JAS Tour And Travel is a market penetration strategy with a total interest score of 6.00 , while the product development strategy has a total score of 5.80 . This shows that the internal factors (strengths and weaknesses) and external factors (opportunities and threats) owned by PT. JAS Tour And Travel supports the market penetration strategy.

Market penetration strategy is a strategy that seeks to increase market share for products or services in the current market through greater marketing efforts. Efforts that can be implemented by PT. JAS Tour And Travel is by implementing a promotion strategy, and a market development strategy, and a strategy to improve the quality of services and services. The market development strategy is carried out by creating various business programs to attract customers and opening branches in various areas outside Medan. Promotional strategies can be carried out by expanding the promotion area and utilizing social media as a means of promotion to reach the wider community. And most importantly, a strategy to improve the quality of services and services to retain loyal customers and get new customers who have the potential to become loyal customers. Based on previous research used by the author, so this study is in accordance with the results of research conducted by Nurcahaya Sianipar (2015), who previously conducted research on topics related to competitive strategy analysis in a thesis entitled "Analysis of Competitive Strategies in Laundry Businesses in Padang Bulan (Case Study on Cheap Laundry) " The results of this study indicate that the right competitive strategy and can be applied by Cheap Laundry in the face of competition is the market penetration strategy. Market penetration strategy is a strategy that seeks to increase market share for products or services in the current market through greater marketing efforts.

The results of the same study are also shown by research conducted by Helen Pryadarsani Harefa (2014), who previously conducted research on topics related to competitive strategy in the thesis "Analysis of SWOT Strategies on Increasing Competitiveness in Joint Supermarkets". The results of the study indicate that the strategic position of the company that has been carried out so far is in the aggressive strategy quadrant. Self-service Together take advantage of these opportunities and strengths and pursue aggressive strategies for self-service growth and development.

Similarly, as shown by research conducted by Fifi Febriana Meliala (2014), previously conducted research on topics related to business competition strategies in a thesis entitled "Shipbuilding Services Business Competition Strategy (Case Study About Implementation of Ship Construction Company Business Strategy CV. Marine Construction Belawan)". The results showed that the strategy that has been applied by CV. Marine Construction Belawan is a diversification strategy that uses a strategy that uses strength to avoid threats. 


\section{CONCLUSION}

The purpose of this study is to answer the formulation of the problem in Chapter I, namely "Which competitive strategy is appropriate and can be applied by the service business actors of PT. JAS Tour And Travel in the face of competition?". Based on the results of the analysis of strategy formulation through 3 stages, namely the input stage using the IFE Matrix, EFE Matrix and CP Matrix; matching stage using SWOT Matrix and IE Matrix; and the last stage is the strategic decision stage using the QSP Matrix, the following conclusions are obtained:

The right competitive strategy that can be applied by PT. JAS Tour And Travel in the face of competition is a market penetration strategy, based on the theory of Fred R. David (2012:252) as previously discussed in Chapter II page 14.

Market penetration strategy is a strategy that seeks to increase market share for products or services in the current market through greater marketing efforts. The market penetration strategy can be applied by PT. JAS Tour And Travel through the SWOT Matrix by implementing promotion strategies, market development strategies, and strategies to improve the quality of services and services.

The market development strategy is carried out by creating various business programs to attract customers and opening branches in various areas outside Medan. Promotional strategies can be carried out by expanding the promotion area and utilizing social media as a means of promotion to reach the wider community. And most importantly, a strategy to improve the quality of services and services to retain loyal customers and get new customers who have the potential to become loyal customers.

\section{REFERENCES}

Alfred, D. Chandler, Jr .1962. Strategy and Structure: Chapters in The History of The industrial Enterprise. Cambridge Mass: MIT Press.

Assauri, Sofjan. 2013. Strategic Management Sustainable Competitive Advantages. Jakarta: Rajawali Pers.

Boyd,dkk. 2000. Manajemen Pemasaran Suatu Pendekatan Strategis dengan Orientasi Global. Jakarta: Erlangga.

Child, John, 1997, "Strategic Choice in the Analysis of Action, Structure, Organization and Environment: Reprospect and Prospect", Organization Studies.

Erawan, I Nyoman. 1994. Pariwisata Dan Pembangunan Ekonomi (Bali sebagaikasus). Bali:PTUpadaSastra.

Fred R. David, 2009, Manajemen Strategis. Salemba Empat Jakarta.

Grant, Robert M. 1999. Analisis Strategi Kontemporer, Konsep, Teknik, Aplikasi. Edisi Kedua. Jakarta : Erlangga.

Hunger, David J \& Thomas L.Wheelen. 2003. Manajemen Strategis. Yogyakarta: Andi.

Hussey, J., Hussey, R. (1997), Business Research : A practical guide for undergraduate and postgraduate students', Macmillan Press Ltd., London.

Kaplan, Robert S dan David P. Norton, 2000, Balanced Scorecard : Menerapkan Strategi Menjadi Aksi, Edisi Indonesia, Tim Penterjemah, Erlangga, Jakarta.

Kotler, Philip.1995.Manajemen Pemasaran. Jakarta. Penerbit Erlangga.

Kuncoro, Mudrajad. 2006. Strategi Bagaimana Meraih Keunggulan Kompetitif. Jakarta: Erlangga.

Porter, M. E. (1980), Competitive Strategy : Technigues For Analizing Industries and Competitors, The Free Press, New York.

Prasetya, Hery dan Fitri Lukiastuti. 2009. Manajemen Operasi. Media Pressindo, Jogjakarta.

Rangkuti, Freddy. 2014. Analisis SWOT Teknik Membedah Kasus Bisnis. Jakarta: Gramedia Pustaka Utama.

Sukmadinata, Nana Syaodih. 2012. Metode Penelitian Pendidikan. Bandung: PT Remaja Rosdakarya.

Umar, Husein. 2005. Strategic Management In Action. Jakarta: PT Gramedia Pustaka Utama.

Sianipar, Nurcahaya. 2015. Analisis Strategi Bersaing Pada Usaha Laundry di Padang Bulan (Studi Kasus Pada Cheap Laundry. Medan: Jurusan IImu Administrasi Niaga/Bisnis Fakultas IImu Sosial dan IImu Politik Universitas Sumatera Utara.

Harefa, Helen Pryadarsani. 2014. Analisis Strategi SWOT Terhadap Peningkatan Daya Saing Pada Swalayan Bersama. Medan: Jurusan IImu Administrasi Bisnis Fakultas IImu Sosial dan IImu Politik Universitas Sumatera Utara.

Meliala, Fifi Febriana. 2014. Strategi Persaingan Bisnis Jasa Konstruksi Kapal (Studi Kasus Tentang Penerapan Strategi Bisnis Perusahaan Konstruksi Kapal CV. Marine Construction Belawan). Medan: Jurusan IImu Administrasi Niaga/Bisnis Fakultas IImu Sosial dan IImu Politik Universitas Sumatera Utara. 